\title{
The Oil and Gas Industry and the Niger Delta: Implications for the Environment
}

\section{*EMOYAN, O. O. ${ }^{\text {a }}$ AKPOBORIE I. A. ${ }^{\text {; }}$ AKPORHONOR E. E. ${ }^{\text {a }}$;}

\author{
${ }^{a}$ Department of Chemistry, and ${ }^{b}$ Department of Geology,Delta State University, Abraka Nigeria.E-mail: onostica_pub@yahoo.com.
} Phone: +2348037410599

\begin{abstract}
The causes of environmental degradation and biodiversity depletion arising from the activities of the oil industry in the region are evaluated. The authors argue that, specific negative impact on the region arising from the activities of the industries include: environmental pollution, biodiversity depletion, social destabilization, underdevelopment of host communities, global warming and associated elevated flood risk Furthermore, a direct consequence of property rights structure following from existing legislature is the underdevelopment of host communities in spite of huge national earnings from oil and gas since 1970. The authors concluded by favouring all embracing and genuine stakeholders participation in environmental and developmental issues in the region. @ JASEM
\end{abstract}

The Niger Delta region is situated in the Gulf of Guinea between longitude $5^{0} \mathrm{E}$ to $8^{0} \mathrm{E}$ and latitudes $4^{0} \mathrm{~N}$ to $6^{0} \mathrm{~N}$, as shown in Figure 1, (Opafunso, 2007). ERML (1997) defines the original Niger Delta region (about 29,900 square kilometers) as comprising the area covered by the natural delta of the River Niger and the areas to the east and west, which also produce oil. Its approximate northern boundaries are located close to the bifurcation of the River Niger at Aboh, while the western and eastern boundaries are around the River Benin and the River Imo respectively. Summary descriptions of its physiography and geology may be found in Allen (1965), Short and Stauble (1967), ERML (1997) and UNDP (2006). It is the largest wetland in Africa and the third largest in the world consisting of flat low lying swampy terrain that is criss-crossed by meandering and anastomosing streams, rivers and creeks.

This well-endowed ecosystem, which contains one of the highest concentrations of biodiversity on the planet, in addition to supporting the abundant flora and fauna, arable terrain that can sustain a wide variety of crops and economic trees, has more species of freshwater fish than any ecosystem in West Africa (Wikipedia 2007). However, this ecosystem is under threat from pollutants generated by a multiplicity of oil and gas related installations, including flow stations, oil well heads, loading terminals and tank farms (Egborge et al., 1986; Onwudinjo 1990). Similarly, Eteng (1997), has argued that, "oil exploration/exploitation has over the last forty years impacted negatively on the socio-physical environment of the Niger Delta oilbearing communities, massively threatening the subsistent peasant economy, the environment and hence the entire livelihood and basic survival of the people". Jimoh and Aghalino, (2000) concur and the UNDP, (2006), forcefully asserts that "the Niger Delta is a region suffering from administrative neglect, crumbing social infrastructure and services, high unemployment, social deprivation, abject poverty, filth and squalor and endemic conflict". It can be concluded therefore that since the commencement of oil and gas exploration/exploitation activities in the region there has been social, economic, health and ecological destabilization, and significant reduction in terrestrial and aquatic life.

Since 1970, crude oil assumed a prime position in the Nigerian economy. Government dependence on oil revenues has also experienced phenomenal increases since 1970. According to the Statistical Bulletin of the Central Bank of Nigeria (CBN, 2004), the average contribution of oil to government export revenue and national earnings between 1970 and 2004 was 93 per cent. The irony is that the region that produces this large percentage of national wealth continues to experience abject poverty, psychosocial and environmental abuse and degradation resulting from the intensive exploration/exploitation of the petroleum resource that is yielding the wealth. This situation is made possible by skewed and cynical national legislation on natural resource ownership, successive years of bad governance, ineffectual policies that are operated by a bloated and obtuse bureaucracy, as well as selfish and irresponsible leadership.

Because of the continued absence of environmental monitoring and surveillance systems in the region even in the face of overwhelming evidence of degradation, this effort reviews in broad strokes the current state of available information on the environment and attempts to further draw attention to some of the factors that have continued and will continue to entrench environmental degradation in the delta while denying overlying communities, access to judicial and constitutional remedies. 


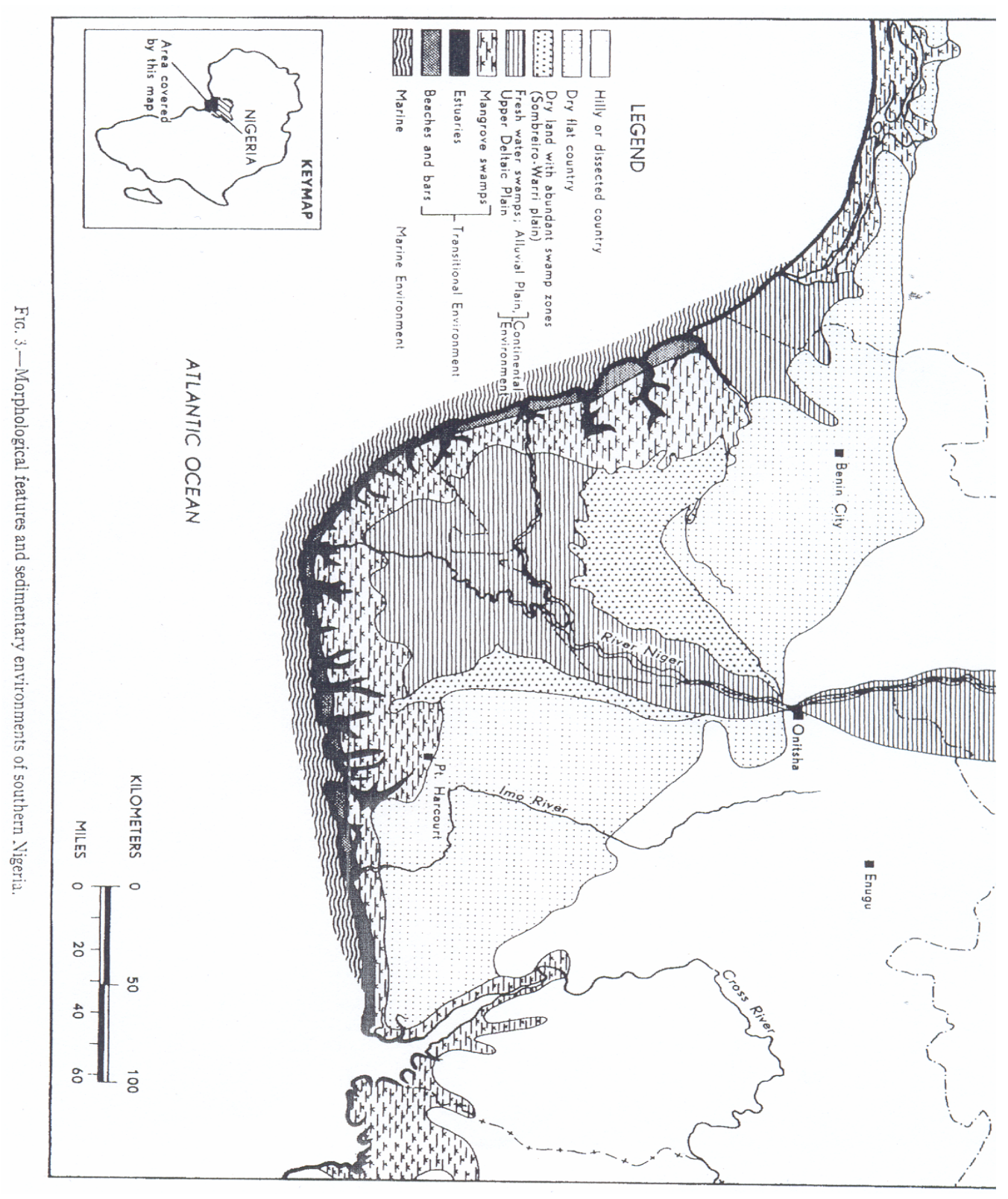

The Petroleum Industry and Air Pollution According to Cedigaz (2000), Nigeria is by far the number one flarer of natural gas on the planet both absolutely and proportionally- about 46 per cent of Africa's total and the most gas flared per tonne of oil produced. The data also indicates that Nigeria accounted for 19.79 per cent of the global figure. Similarly, analytical assessment of the statistical bulletin of the Central Bank of Nigeria, (2004) showed that the average rate of gas flaring in Nigeria during the period 1970-1979 stood at 97\%, while $97 \%$ and $95 \%$ were flared between 1980 and 1989, and 1990 to 1999 respectively. Between 2000 and $200451 \%$ was flared. In the same vein, between 1970 and 2004 Nigeria has flared and average of $76 \%$ of the total gas produced. Much of the natural gas extracted in oil wells in the Niger Delta is immediately flared into the environment at a rate that approximates 70 million $/ \mathrm{m}^{3}$ per day. This is equivalent to $40 \%$ of African natural gas consumption and forms the single largest source of greenhouse gas emissions on the planet (Wikipedia 2007, Moffat and Linden, 1995). Orubu, (2002b), who undertook a comparison of concentrations of ambient air pollutants in the region and Lagos State concludes that pollutant concentrations are highest in the Niger Delta and argues that some of the green house gases (such as methane and carbon dioxide) emitted at flare sites contribute to global warming This suggests therefore that Nigeria oil fields contribute more to global warming (through flaring of associated gas) than the rest of the world. The largest proportion of these flare sites are located in the Niger Delta. Moreover, gas flare sites around the region generate tremendous heat thereby causing thermal pollution. Ogbuigwe 
(1998), reports that temperatures produced at flare sites could be as high as $1,600^{\circ} \mathrm{C}$. Temperature as high as $40^{\circ} \mathrm{C}$ at an average distance of 43.8 metres from flare sites in Isoko, Delta State have been recorded by Alakpodia, (1989, 1995) has also shown that such flares have negative effects on vegetation growth, animal life and ecological equilibrium in the Niger Delta area.

In addition, an assessment made by the Intergovernmental Panel on Climate Changes (IPCC), cited in Magbagbeola, (2002) noted that as a result of global warming, an associated sea level rise (SLR) will have serious and global consequences for low lying coastal areas and island states. Awosika and Foluronsho, (2006) has documented projected impacts of SLR on the Nigerian coastal area and resources and these include: large scale inundation, increased coastal erosion, salt water intrusion into coastal aquifers, habitat modification with direct effects on wild life distribution, increased frequency of high intensity rainfall events and associated increased run off, elevated erosion rates, flash floods and increased frequency of ocean storm surges. The combined effects of all these would jeopardize the survival of coastal communities. Already, annual erosion rates have been estimated at 18-24 meters at Ugborodo, 20-22meters at Forcados, 16-19meters at Brass, 1520 meters at Kulama, 20-24 meters at Bonny and 10-14 meters at Opobo River estuary (Ibe et al. 1984). Indeed, while Awosika et al. (1993) project a loss of up to $15,000 \mathrm{~km}^{2}$ by the year 2100 as a result of a 1m SLR, Magbagbeola, (2002) projects flooding of over $18,000 \mathrm{~km}^{2}$ land area for the delta in an SLR of $1 \mathrm{~m}$ per 100 years.

Finally, the effects of gas flares on vegetation and microclimate, surface and ground water through acidification of rain water could be profound. Oluwole et al.(1996) in a comprehensive air quality assessment of the Niger Delta show that the levels of concentration of volatile oxides of carbon, nitrogen, sulphur oxide and total particulates exceed existing Federal Environmental Protection Agency's (FEPA,1991) standards. Olobaniyi and Efe (2007) also show elevated levels of lead (0.56 $\mathrm{mg} / \mathrm{l})$ and low $\mathrm{pH}$ values ranging from $5.10-6.35$ in rain water collected in Warri and environs. Akpoborie, et al, (2000) also report low $\mathrm{pH}$ values from water obtained from shallow hand dug wells in Ughelli, Warri, and Okurekpo all in Delta State. Acidified rain water does not only corrode roofing sheets, monuments and other economic structures it can also damage vegetation and contaminate ponds and lakes which are the sources of livelihood to overlying indigenous rural communities in the delta.

\section{The Degradation of Land, Forest and Water Resources}

The United Nations' Human Development Report of the Niger Delta among several alarming declarations on the state of the region's environment asserts that "there is a strong feeling in the region that the degree and rate of degradation are pushing the delta towards ecological disaster" (UNDP, 2006). This feeling is buttressed by results of research.

An impact assessment of the 1983 Oshika oil spill by Powell and White (1985) confirmed the death of floating and submerged aquatic vegetations especially water lettuce, crabs, fish and birds. Atuma and Egborge (1996), NDES (1997), Egborge, (2000) Orubu et al., (2002), and Otukunefor and Biukwu (2005) have all shown that the pollution levels of aquatic ecosystems observed in the region are a result of unregulated effluent discharges and unsustainable methods of petroleum extraction. Amakiri (2005) laments the loss of biodiversity, alteration of habitats and deforestation that is associated with petroleum exploitation related canalization. This canalization which is quite extensive in the region opens up previously pristine and inaccessible ecosystems to illegal logging activities. Ndiokwere and Ezehe (1990), also report high levels of heavy metals in soils and plants near the Warri Refinery. Emoyan et al., (2006a, 2006b) have also confirmed high levels of heavy metal contamination of River Ijana - an effluent receiving stream that flows by the same refinery. Braide et al., (2004) observed high concentrations of heavy metals in the Miniweja stream in the eastern Niger Delta. Furthermore, Spiff and Horsfall, (2004) reported trace metal contamination of the intertidal flats of the Upper New Calabar River in the Niger Delta.

Meanwhile, Rowell (1977), Atuanya (1987), Anoliefo and Vwioko (1994), Anoliefo(1991), Gill et al. (1992) and Agbogidi et al. (2006) have independent studies, that documented the adverse effects of crude oil, engine oil and spent lubricating oil on soils and the suppression of germination of seeds, regeneration as well as stomata abnormalities in diverse food crops.

The major sources of degradation of forests, land and water in the region include oil spills, gas leaks, blowouts, canalization and the discharge of wastes and effluent from oil and gas operations directly into surface water bodies and the land surface.

Oil spills in Nigeria occur due to a number of causes that include corrosion of pipelines and storage tanks, sabotage, and accidents in oil production operations. A World Bank survey (Grevy, 1995) estimated that about 2.3million cubic metres of crude oil is spilt in about 300 separate incidents in the region each year; observed that oil companies deliberately understate the incidents of oil spillage, and that the total volume of oil spilt might be as much as ten times the official figures. The official figures of SPDC (2004) show that between 1976 and 2001, 6,187 incidents in which 3 million barrels were spilled. Greater than 70 per cent of this volume went unrecovered (UNDP,2006). Following from Grevy's (1995) assertion, it may be concluded that 
more than 30 million barrels have been spilled into the delta environment in the same period. Also, the Funiwa 5 oil well blowout in 1980 and Jones Creek oil spillage of 1998. These two spills together resulted in greatest mangrove devastation ever recorded worldwide.

In addition to deforestation, spills deplete aquatic fauna. The spilled oil and indeed untreated oil industry related effluent are considered priority pollutants as they interfere with biological life in surface waters creating unsightly floating matter and film. This situation is of high ecological concern as a result of simultaneous transformation of oily compounds by biochemical, chemical, microbiological and photochemical processes. The consumption of dissolved oxygen by bacteria feeding on the spilled hydrocarbons also contributes to the death of fishes.

The Niger Delta Environmental Survey (NDES, 1997) attributes some of the reasons for the high incidence of spills as the very old age of the pipelines and the lack of regular inspection and maintenance. Corrosion of equipment which account for high percentage of all spills could be related to the small size of the oil fields in the Niger Delta which has an extensive network of pipelines, between the fields as well as numerous small networks of flow lines -that carry oil from wellheads to flow stations, allowing many opportunities for leaks. These pipelines which were laid about 50years ago according to the then prevailing standards and estimated to have a life span of about fifteen years are old and susceptible to corrosion. Poor management practices are common features around oil installations leading to oil leaks and spills in the region.

Leaks and spills also affect ground water quality. Preliminary results of ongoing ground water quality evaluation around the WRPC show elevated levels of BTEX in shallow boreholes and dug well water (Akpoborie et al. 2008). This is interesting because Warri, an oil town of more than forty years, and arguably the most important industrial centre in southwestern Nigeria does not have a reliable public water supply system, and consumers must rely on private sources, usually shallow boreholes and hand dug wells. Indeed, this is the situation in most parts of the delta. Because water table conditions are prevalent, depth to water is on average less than a meter in the wet season and the topography is virtually flat, spills as well as effluent impact directly on ground water. The situation is compounded by the fact that there is neither water quality surveillance nor monitoring systems anywhere in the region. As it is well known, unrecovered spilled hydrocarbon could under these conditions be retained for years in the vadoze zone as well as on the phreatic surface from where it would serve as a continuous water supply contaminant point source.

\section{Legislative Framework and Environmental Sustainability}

Nigeria's environmental legislation especially as it is related to the oil and gas industry is fragmented as it consists of several legislative acts, regulations and decrees. Beyond this, several reviews of these laws have revealed problems that militate against the achievement of environmental sustainability, the primary objective of legislation. They also prevent overlying communities from obtaining redress when pollution occurs, within the legislative framework, Babington - Ashaye (2005). First, the emergence of appropriate environmental laws should ideally reassure all concerned that the environment is being protected; however there is such deep seated distrust between government, regulatory agencies, petroleum industry operators and communities that even the best intentions are often misunderstood. In any case, these regulatory agencies are not independent of government, which itself is a shareholder in the major upstream oil and gas companies. This is a fundamental issue, as amply demonstrated in the Ozoro waste injection facility (Akpoborie and Diwanbor, 2007) where it appears that the mandatory environmental impact assessment process was ignored in the permit process that authorized the injection of supposedly oil field wastes brought into the site from elsewhere. The Ozoro community's immediate protest was given relatively shabby treatment by the regulatory agencies.

In fact, it has been argued that the environmental statutes as they presently are do not explicitly recognize the host community as a stakeholder in environmental management and compliance monitoring. Because the regulatory agencies that are mandated with environmental management have severely limited manpower and financial resources, therefore with appropriate assistance, communities and local governments could be empowered to become responsible for and be watchdogs of their own environment. A fully aware community should be an asset and partner to environmental management agencies.

Adjudication has also revealed difficulties facing individuals and communities that seek to obtain remedies, redress and justice from the judicial process. These problems include the fact that the rules of evidence place the burden of proof of pollution or environmental degradation on the plaintiff community or individual. The oil and gas companies have always taken advantage of this fact. Communities are incapable of mustering the financial resources and expertise required to provide such proof. On the other hand, the offending and defendant company has an arsenal of resources to be deployed and the courts have been obliged to decide in favour of the defendant in such cases. It has therefore been suggested (Osipitan, 1990) that the laws be amended to shift the burden of proof to the polluting firm. 
Seeking relief in nuisance cases is even more difficult because the laws are crafted in such a way that only the Attorney General can initiate proceedings on behalf the public, or in this case, the offended community. Experience shows that, communities have had little success in convincing the Attorney General to initiate such cases. When state law officers decline prosecution, the scope of private prosecution which is by leave of the courts is severely limited by existing court procedures. Commenting on this situation, Taiwo Osipitan poses the following questions:

" should a genuinely aggrieved plaintiff, be prevented from commencing an action to enforce his legitimate rights to a clean and hazard-free environment if the Attorney-General is unconcerned with his plight? Should the requirement of proof of special damages foreclose a citizen's right to decent environment?" (Osipitan, 1990,).

One remedy therefore, is to grant an unrestricted right of enforcement of environmental laws to communities and citizens. A sure and simple way of doing this is the abrogation of the offensive Land Use Decree of 1976 that has disenfranchised Nigerians of their rights to land and ceded it to government. Furthermore, because scientific evidence in environment problems is multi faceted and multidisciplinary and can thus be quite complex, the legal profession admits to a dearth of interdisciplinary expertise in its ranks which results in apathy on the part of lawyers to really appreciate this complexity. As a result, Osibanjo (1990) has advocated the establishment of special courts or tribunals with judges and assessors to handle environmental problems.

\section{DISCUSSION}

This review which is far from exhaustive has shown that there is evidence of the clear and present danger of environmental degradation of air, land and water resources from gas and oil production activities in the delta. What is more, there are enough resources being generated to allow for internalization of the environmental costs. The technology to do this is also available. Unfortunately, the lack of political will engendered by selfish and short sighted governance has precluded the emergence and application of fair and practical solutions. Aside from the usual rhetoric, the past two decades have witnessed the emergence of hard data on the problem. However, it could be better. For example an innocuous but fundamental fact that has eluded all commentaries on the Niger Delta environment is that the most important piece of legislation on the environment, Decree 58 of 1988 was enacted a clear 38 years after the first oil well was spudded in Nigeria. The question is: what happened to all the degradation and dumping of waste that occurred pre -Decree 58 ? It is not as if Nigeria is unaware of the U.S.
Superfund program by which the American government has committed and still commits billions of dollars and other resources to clean up decades of environmental degradation resulting from industrial activity. That Decree 58 was the fallout from the illegal dumping of toxic wastes allegedly imported from overseas at Koko in the beleaguered delta speaks volumes for the seeming lethargy of governance in Nigeria with respect to the environmental problems not only of the region but of the entire country.

With respect to climate change and air pollution in the delta, the data is scanty. However, the evidence of acidity, elevated levels of lead in rainwater and shallow ground water is unmistakable. Research and the establishment of data gathering systems are basic and necessary requirements to determine the magnitude and extent of the problem as a prelude to designing solutions. An earlier study by Douglas et al, (2005) on the effect of deforestation on tropical basin hydrology has also associated an increase of 1 per cent basin yield for every 3 per cent forest loss thereby increasing the probability of flooding. Efforts at developing the region through various intervention schemes and agencies have been dismal failures as a result of insincerity, dishonesty and lack of commitment on the part of the federal government that initiated the schemes. The most recent federal intervention programme is the Niger Delta Development Commission (NDDC), which developed a master plan for the region in 2007. Spread over fifteen years, the plan is to address among others, the problems of the natural environment. Plan recommendations in this regard are as follows:

\section{"POLICY EN5 - MANAGEMENT OF BIOLOGICAL RESOURCES}

Efforts shall be made to move the responsibility to manage biological resources more to the local level.

One of the major challenges in safeguarding the natural environment is the lack of interest in the subject in communities where activities that have a detrimental impact, such as deforestation are a necessity for survival. It follows that an important part of the enabling environment for the conservation of biodiversity, is meaningful progress toward the reduction of poverty in the Region, which is one of the core principles of the Master Plan.

\section{POLICY EN7 - AIR QUALITY}

An air quality strategy will be introduced to achieve reductions in emissions from all sources. It will include monitoring mechanisms, regulations and enforcement measures, and planning policies to minimize pollution by future development.

The NDDC will collaborate with Government Agencies to introduce an air quality strategy for the Region. This will focus on the reduction of 
pollution levels from vehicles, industry, gas flaring and domestic burning of timber, to permissible levels as defined in national and international standards.

The impact of air pollution from industrial and vehicular sources on the health of the communities in the Region and its biodiversity needs to be thoroughly researched as first step towards the production of an air quality strategy for the area. The finding should be widely publicized to create public interest and an incentive for action.

Existing air quality monitoring programmes will be examined and new ones introduced to determine the most effective means of merging national programmes with Regional projects to improve air quality. (See also Policies PI 6 and PI 7).

Motor vehicles annual testing and other regulations have to be created or re-introduced and strictly enforced.

\section{POLICY EN8 - WATER QUALITY}

Invest in institutional structures to support a programme for supply water resource management including the provision of rainwater harvesting and conservation in remote areas.

Provision will be made for creating an institutional and management framework for water quality monitoring including the development and implementation of a system of water quality assurance consistent with WHO standards. The NDDC will liaise with State water agencies to determine the most effective plan of action for the implementation of a water resources management and development strategy based on the detailed research undertaken as part of the Master Plan"

As can be seen, these are general statements that lack specificity, the hallmark of scientific investigation. A blueprint for defined geographical areas is what is required as was done (or is being done) for the Ogoni area by a UNDP/UNEP collaborative effort. Given the history of dismal federal interventions in the Niger Delta, the recommendations of the master plan are not expected to do much in improving environmental management in the region. A specific, agency outside and independent of existing institutions to specifically address sustainable environmental management in the region is a requirement.

If as in the words of President Olusegun Obansanjo at the presentation of the Master Plan ".....the region is pregnant with great potentials for the development of the rest of the country" (Tell, 2007), should this development be at the expense of the environmental degradation of the region where the oil occurs? As has been shown in the foregoing, existing laws have not only divested the people and communities in the delta of their natural title to ownership, control and management of their land and resources the law also does not provide avenues for redress. The result is that they remain poor cousins of their counterparts in other parts of the world who are also blessed with petroleum beneath their feet. This is clear from the UNDP (2006), which compares the Human Development Index across oil producing countries and the Niger Delta. The delta region trails in all indices.

Nigeria has indeed been found guilty of violating Articles 21 and 24 of the African Charter on Human and People's Rights by the African Commission on Human and People's Rights (ACHPR) sitting in Banjul, Gambia from $13^{\text {th }}$ to $27^{\text {th }}$ October 2001 . Article 21 of the Charter states in part, that:

1. All peoples shall freely dispose of their wealth and natural resources. This right shall be exercised in the exclusive interest of the people. In no case shall a people be deprived of it.

2. In case of spoliation the dispossessed people shall have the right to the lawful recovery of its property as well as to an adequate compensation.

Article 24 also states: All peoples shall have the right to a general satisfactory environment favorable to their development. Issuing the "Finding" in the suit brought against Nigeria by SERAC a human rights Non Governmental Organization for human Rights violation in Ogoni land ( ACHPR, 2001) the Commission also appealed to the government of Nigeria to undertake comprehensive clean up of lands and rivers damaged by oil operations as well as ensure that appropriate environmental and social impact assessments are prepared for any future oil development and that the safe operation of any further development be guaranteed through effective and independent oversight bodies for the petroleum industry (ACHPR, 2001). Nigeria's environmental agencies remain ineffective and are certainly not independent of government. Consequently, the agitation for compensation for oil pollution is a continuous and contentious one in the Niger Delta, as the question often arises as to who should be compensated and how much. The arguments often raised by the industry usually revolve around the fact that the Federal Government receives large sums in fees, rents and royalties and should be responsible for environmental management as well as compensation for any degradation. The agitation for adequate compensation, environmental protection and conservation and equitable distribution of oil wealth has recently metamorphosed into upheavals, seizure of oil installations and hostage taking resulting in the loss of lives and property. The recent guerilla/non violent activity by the Movement for the Emancipation of the Niger Delta (MEND), Niger Delta Volunteer Force (NDVF), Niger Delta Freedom Fighters (NDFF), Movement for the Survival of the Ogoni People (MOSOP), Ijaw Monitoring Group (IMG) etc are typical examples. It is thus clear, that there are many difficulties with 
the existing legislative framework for upstream regulation of the oil and gas industry. Enforcement is rendered impossible because enforcement provisions are weak and the institutions are ill-equipped and avenues exist for corruption. Finally, the political will that engenders good governance is lacking.

\section{CONCLUSIONS AND RECOMMENDATIONS}

Huge revenues are realized from the extraction of petroleum resources at the expense of the degradation of air, water, land and forest resources in the Niger Delta. This degradation has been a continuous process for nearly forty years before the enactment of formal environmental legislation. Previously degraded areas must be identified and rehabilitated. This is consistent with the a major goal of the National Policy on Environment(NPE), (FEPA, 1991) Section 2(c) which is to " restore, maintain and enhance the ecosystems and ecological processes essential for the functioning of the biosphere to preserve biological diversity and the principle of optimum sustainable yield in the use of living natural resources and ecosystems" It has also been shown in the foregoing that existing federal environmental legislation is amorphous in addition to being inequitable with respect to overlying communities in the delta. In possible recognition of these shortcomings, the NPE also stipulates at Section $8 \mathrm{~b}$ that existing laws be streamlined into a holistic and integrated compact in addition to prescribing jurisdictional boundaries for environmental law making (Section 8c).

Consequently, it is recommended that the Land Use Decree of 1976 be abrogated and replaced by a more equitable and less cynical legislation that recognizes land and natural resource ownership rights. Special courts or tribunals should then be set up to adjudicate on environmental disputes in the delta. In addition, the delta should be declared an ecological disaster area that is desirous of special attention and special rehabilitation measures. Funding for this measure should be obtained from the huge revenues that have accrued from the current unprecedented increase in crude oil prices. A specific agency to manage this ecological disaster area and which is independent of existing agencies should manage this problem. Further funding of the agency would be as provided for in detail as specified at Section 10 of the NPE.

\section{REFERENCES}

African Commission on Human and People's Rights, (2001), ACHPR Decision 155/96 The Social and Economic Rights Action Center and the Center for Economic and Social Rights/ Nigeria.
Agbogidi, O.M., Eruotor, P.G.; Akparobi, S.O. (2006), Effects of Soil Contaminated with Crude Oil on the Germination of Maize (Zea Mays L.), Nig. Jnr. of Sc. and Env., 5:1-10.

Akpoborie, I. A.; Diwanbor, G. U. (2007), Do Environmental Laws in Nigeria Encourage Conflict? A Case Study Of The Ozoro DeepWell Waste Injection Facility, In, Readings in Conflict Management and Peace Building in Africa, Eds. Omotor, D.G. et al., Vol. 2:

Akpoborie, I.A.; Ekakite, A. O.; Adaikpoh, E.O. (2000), The Quality of Groundwater from Dug wells in Parts of the Western Niger Delta, Knowledge Review 2: 72-79.

Akpoborie,I.A., Emoyan, O. O.; Asagba, S. O.; Balogun, A. Y. (2008), Aromatics in Private Water Supplies in Warri, Delta State, Nigeria. Scientia Afr. (7)1:74-80

Alakpodia, I J (1989), The Effects of Gas Flaring on the Micro-climate and Adjacent Vegetation in Isoko Area of Bendel State" (Unpublished M.Sc Thesis, University of Ibadan).

Alakpodia, I. J. (1995), "The Oil Industry and the Economic Environment of the Niger Delta" Paper presented at the $30^{\text {th }}$ Annual Conference. Nigeria Geographical Association, at the University of Benin. Benin City. Nigeria.

Allen, J.R.L., (1965), Late Quaternary Niger Delta, and Adjacent Areas: Sedimentary Environments and Lithofacies, Bull. AAPG (49) 5:547-600.

Anoliefo, G.O.; Vwioko, D.E., (1994), Effects of spent lubricating oil on growth of Capsicum annum L. and Lycopersicon esculentum (Miller), Environmental Pollution 88: 361-364.

Anoliefo, G.O., (1991), Forcados blend crude oil effects on respiratory mechanism, mineral element composition and growth of Citrullus vulgaris Schead, Unpublished Doctoral Thesis, University of Benin, Benin City, Nigeria.

Atuanya, E. I. (1987), Effects of waste engine oil pollution on physical and chemical properties of soil: A case study of waste oil contaminated Delta soil in Bendel State, Nigerian Journal of Applied Science, 5: 155-175.

Awosika, L F; Ojo, O; Ajayi, T A, (1993), Implications of Climate changes and Sea Level Rise on the Niger Delta, Nigeria. Phase 1, A Report for UNEP, Nairobi.

Awosika, L.; Foluronsho, R. (2006), Climate Change and Impact on the coastal environment of Nigeria, In, Sustainable Environmental 
Management in Nigeria, Eds. Ivbijaro et al. Mattivi Productions, Ibadan, pp 85-103.

Babington-Ashaye, A (2005), Evaluating the Legislative Protection of Social-Economic Rights in the Niger Delta. In: Perpetuating Poverty, Consolidating Powerlessness: Oil and the Niger Delta. (Ed); Morka K. 109-115.

Cedigaz, (2000) www.cedigaz.org.

Central Bank of Nigeria. (2004), Statistical Bulletin 15

Egborge, A B M (2000), Government, Oil Companies, The Peoples and the Niger-Delta Environment: 4th Convocation Lecture of Delta State University, Abraka. Nigeria. 106.

Egborge, A B M; Okoro, J I; Alawani, O A; Uriah, N (1986), Thermal and Chemical Pollution of Benin River and its Tributary, the Jamieson river in Nigeria. Nigerian Journal of Applied Science 4:121-149.

Emoyan O O; Akporhonor, E E; Akpoborie, I A; Adaikpoh, E O (2006), Water Quality Assessment of River Ijana, Ekpan, Warri, Delta State, Nigeria. Journal of Chemical Society. Nigeria, 31(1\&2), $154-160$.

Emoyan, O O; Ogban, F E; Akarah, E (2006), Evaluation of Heavy Metals Loading of River Ijana, Warri Nigeria. Journal of Applied Science and Environmental Management. 10 (2) $121-127$.

Environmental Resources Management Ltd. (1997), Environmental and Socioeconomic Characteristics of the Niger Delta. ERML, Lagos.

Eteng, I A (1997), The Nigerian State, Oil Exploration as community Interest: issues and Perspectives" University of Port Harcourt, Nigeria.

Federal Environmental Protection Agency, (1991), National Policy on the Environment, The Presidency, Abuja, Nigeria. 43

Gill, L. S.; Nyawuame, H. G. K.; Ehikhametalor, A. O. (1992), Effect of Crude oil on growth and anatomical features of Chromolaena odorata L. Newsletter 5:46-50

Grevy, P. (1995), The Niger Delta in Nigeria: A Pollution Assessment Study, World Bank, Washington D.C.

Ibe, A.C.; Awosika, L. F.; Antia, E. E. (1984), Progress Report No.2. Coastal Erosion Project. NIOMR Special Publication. 106.
Jimoh, H I; Aghalino, S. O. (2000), Petroleum and Environment Degradation: A Perspective on Government Policies in Nigeria, In: Contemporary Issues in Environmental Studies. (Eds) Jimoh, H.I. and Ifabiyi I.P. 238244.

Magbagbeola, I (2002), Environmental Underdevelopment of the Niger Delta: An Eclectic view, In: The Petroleum Industry, Economy and the Niger-Delta Environment. (Eds), Orubu. C, Ogisi, D.O. and Okoh R.N. 32-40.

Moffat, D; Linden O (1995), "Perception and Reality Assessing Priorities for Sustainable Development in the Niger Delta, Journal of the Human Environment, 24 No 7-8 327-538.

Ndiokwere, C L; Ezehe (1990), "The Occurrence of Heavy Metals in the Vicinity of Industrial Complexes in Nigeria" Environmental International. 16. 291-295.

Niger Delta Environmental Survey (NDES) (1997), Environmental and Socio Economic Characteristics.

Ogbuigwe, A (1998), "Judicial Activism in the Enforcement of Environmental Regulations in the Petroleum Industry: Past, Present and the Future." Proceedings of 1998 International Conference on the Petroleum and the Nigerian Environment 83-123.

Olobaniyi, S.B.; Efe, S.I. (2007), Comparative assessment of rainwater and groundwater quality in an oil producing area of Nigeria: environmental and health implications, Journal of Environmental Health and Res. (6)2: 111118 .

Oluwole, A.F.; Olaniyi, H.B.; Akeredolu, F.A.; Ogunsola, O.J.; Obioh, I.B. (1996), Impact of the Petroleum Industry on Air Quality in Nigeria, Presented at the $8^{\text {th }}$ Biennial International Seminar on the Petroleum Industry and the Nigerian Environment, Port Harcourt, 17-21 November.

Onwudinjo, C C (1990), Hydrology and Plankton of Benin River, Nigerian. Ph.D. Thesis, University of Benin, Nigeria.

Opafunson, Z. O. (2007), 3D Formation Evolution of an oil field in the Niger Delta Area of Nigeria using Schlumbeger Petrol Workflow Tool. Journal of Engineering and Applied Science 2(11) 1651 - 1660.

Orubu, C O (2002a), Petroleum-Induced Environmental Diseconomies and Sustainable 
Development. In: The Petroleum Industry, the Economy and the Niger-Delta Environment. (Eds), Orubu, C.O., Ogisi, D.O. and Okoh, R.N. 17-31.

Orubu, C O (2002b), Oil Industry activities, Environmental Quality, and the Paradox of Poverty in Niger Delta. In: The Petroleum Industry, the Economy and the Niger-Delta Environment. (Eds), Orubu, C.O., Ogisi, D.O. and Okoh, R.N. 17-31.

Orubu, C O; Ogisi, D O; Okoh, R N (2002), The Petroleum Industry, Economy and the NigerDelta Environment. (Eds), Orubu. C, Ogisi, D.O. and Okoh R.N. 211.

Osibanjo, Y., (1990), Some Public Law Considerations in Environmental Protection, In, Environmental Laws in Nigeria, Ed. Omotola, J.A. Faculty of Law, University of Lagos, pp 128-149.

Osipitan, T., (1990), Problems of Proof in Environmental Litigation, In, Environmental Laws in Nigeria, (Ed.) Omotola, J.A. Faculty of Law, University of Lagos, pp 112-127.

Otukunefor, T V; Biukwu C O (2005): Impact of Refinery Influent on Physico-chemical Properties of a Water body on the Niger Delta. Applied Ecology and Environmental Research. 3(1) 61-72.
Power and White, (1985), An Impact Assessment of the 1983 Oshika Oil Spill.

Rowell, M. J., (1977), The effect of crude oil on soils: a review of the literature, In, Toogood, J.A.(ed.), The reclamation of agricultural soils after spills, Part 1, Edmonton Publishers, Canada, pp 1-33.

Shell Petroleum Development Company (2004), Annual Report.

Short, K.C.; Stauble, A.J. (1967), Outline of Geology of Niger Delta, Bull. AAPG (51)5: 761-779.

Spiff, A I; Horsfall, M Jnr (2004), Trace Metal Concentrations in Inter-Tidal flate Sediments of the Upper New Calabar River in the Niger Delta area of Nigeria. Scientia Africana. 3. 1928.

Tell, (2007), Olusegun Obasanjo's Speech at the Presentation of the Niger Delta Regional Development Master Plan. 23.

U N D P (2006), Niger Delta Human Development Report. Pp 229

Wikipedia (2007), http://en.Wikipedia.org/Wiki/ Environmental Issues in Nigeria/Niger Delta.

World Bank (1995), Defining an Environmental Strategy for the Niger Delta. Washington D.C. Industry and Energy Operations Division (West/Central Africa Department). 